\title{
Analisis Persepsi, Perilaku dan Preferensi Masyarakat Terhadap Penggunaan Ulang Ovo di Surabaya
}

\author{
(The Analysis of Perception, Behavior, and Community Preference \\ Toward the Reuse of OVO in Surabaya)
}

Oleh:

\author{
M. Richowanto'), Ety Dwi Susanti'2) \\ Universitas Pembangunan Nasional "Veteran" Jawa Timur1),2) \\ richowanto2@gmail.com ${ }^{1)}$,etydwisantoso@gmail.com ${ }^{2}$
}

Accept: 25 May 2021

Publish: 26 May 2021

\begin{abstract}
ABSTRAK
Penelitian ini menggunakan metode kuantitatif. Populasi dalam penelitian ini adalah pengguna dompet digital (e-wallet) OVO di Surabaya. Jumlah sempel yang digunakan adalah sebanyak 100 responden dengan menggunakan metode purposive sampling. Teknik analisis data menggunakan teknik analisis regresi linier berganda dengan bantuan alat hitung SPSS for windows versi 23.0. Temuan penelitian ini menunjukkan bahwa: (1) Persepsi masyarakat berpengaruh positif dan signifikan terhadap penggunaan ulang dompet digital (e-wallet) OVO di Surabaya. (2) Perilaku masyarakat berpengaruh positif dan signifikan terhadap penggunaan ulang dompet digital (e-wallet) OVO di Surabaya. (3) Preferensi masyarakat berpengaruh positif dan signifikan terhadap penggunaan ulang dompet digital (e-wallet) OVO di Surabaya. Penelitian ini menghasilkan kesimpulan bahwa variabel persepsi masyarakat, perilaku masyarakat, dan preferensi masyarakat berpengaruh signifikan terhadap penggunaan ulang dompet digital (e-wallet) OVO di Kota Surabaya.
\end{abstract}

Kata kunci:

Persepsi Masyarakat; Perilaku Masyarakat; Preferensi Masyarakat; Penggunaan Ulang

\begin{abstract}
This research uses quantitative methods. The population in this study were users of the OVO digital wallet in Surabaya. The number of samples used was 100 respondents using purposive sampling method. The data analysis technique uses multiple linear regression analysis techniques with the help of the calculation tool SPSS for windows version 23.0. The findings of this study indicate that: (1) Community perception has a positive and significant effect on the reuse of the OVO digital wallet in Surabaya. (2) Community behavior has a positive and significant effect on the reuse of the OVO digital wallet in Surabaya. (3) Community preference have a positive and significant effect on the reuse of the OVO digital wallet in Surabaya. This study resulted in the conclusion that the variables of community
\end{abstract}


perception, community behavior, and community preference had a significant effect on the reuse of the OVO digital wallet in Surabaya.

\section{Keywords:}

Community Perception; Community Behavior; Community Preference; Reuse

\section{PENDAHULUAN}

Perkembangan teknologi serba digital seperti sekarang ini mampu mengubah tatanan kehidupan masyarakat serta membawa perubahan pada sistem bertraksaksi yang dapat dilakukan secara online. Perubahan sistem transaksi ini didorong oleh besarnya volume dan nilai transaksi, peningkatan resiko, serta kompleksitas transaksi serta didukung oleh semakin banyaknya pusat perbelanjaan yang sistem transaksinya berupa pembayaran uang elektronik (emoney). Saat ini penggunaan dompet elektronik (e-wallet) sudah meningkat dengan adanya banyak faktor yang mendukung, salah satu pengguna utama adalah kalangan remaja dan mahasiswa dalam generasi muda masa kini. Less Cash Society merupakan suatu gerakan masyarakat untuk melakukan transaksi nontunai dalam kehidupan sehari-hari. Realisasi Less Cash Society tidak hanya mengacu pada perubahan sistem, namun lebih mengarah pada perubahan dalam berperilaku dan budayanya (Aulia, 2019).

Berdasarkan data dari situs iprice.co.id dari kuartal II tahun 2019 sampai dengan kuartal II tahun 2020, dapat disimpulkan bahwa aplikasi dompet digital terbesar di Indonesia tahun 2019-2020. Pada kuartal II 2019 urutan keempat teratas yaitu Gopay dengan posisi pertama disusul OVO, Dana dan berikutnya LinkAja. Pada kuartal II 2019 sampai kuartal II 2020 tidak terjadinya pergeseran peringkat untuk 4 besarnya tersebut. Gopay, OVO, Dana, dan LinkAja yang merupakan 4 E-Wallet pengguna aktif bulanan dengan jumlah terbanyak diperiode tersebut, maka pastinya juga merupakan total unduh terbanyak untuk aplikasi tersebut kecuali pada periode kuartal II 2019, Dana menggantikan OVO diposisi kedua setelah Gopay namun hal ini terjadi hanya dalam satu kuartal itu saja.

Fenomena peningkatan persentase indeks ini dapat mengindikasikan bahwa telah terjadi perubahan perilaku masyarakat, yang saat ini banyak beralih menggunakan dompet digital sebagai alat bertransaksi secara berulang. Fenomena ini dianggap hal yang penting karena dapat mempengaruhi perkembangan penyedia layanan dompet digital dan telah mendasari berbagai penelitian (Latifah, 2020).

Pembelian ulang merupakan pembelian berdasarkan atas pengalaman yang telah dilakukan pada masa lalu. Keputusan untuk menggunakan atau menolak suatu produk setelah konsumen berhasil menggunakan suatu produk tersebut dan muncul persepsi suka atau tidak terhadap produk tersebut. Persepsi menyukai suatu produk muncul apabila konsumen merasa bahwa produk yang digunakannya memiliki kualitas dan berhasil memenuhi keinginannya. Hal ini memiliki arti bahwa, semakin tinggi nilai yang melekat terhadap suatu produk atau jasa maka akan memicu tingkat penggunaan ulang (Sartika, 2017). Penggunaan ulang dipengaruhi oleh beberapa faktor, seperti persepsi (Basyar dan Sanaji, 2016), perilaku (Erviatin, 2019), dan preferensi (Putri dan Nugroho, 2015). 
Persepsi merupakan suatu proses dimana individu melakukan pengorganisasian terhadap stimulus yang diterima dan menginterpretasikan, sehingga seseorang dapat menyadari dan mengerti apa yang diterima dan hal ini juga dapat di pengaruhi oleh pengalama pengalaman pada individu yang bersangkutan (Jayanti dan Arista, 2018). Persepsi sebagai proses bagaimana stimulistimuli diseleksi, diorganisasikan, dan diinteprestasikan. Stimuli sendiri adalah setiap bentuk fisik, visual atau komunikasi verbal yang dapat mempengaruhi tanggapan individu seperti bentuk, suara, bau, dan rasa (Setiadi, 2013). Suatu merek yang dipersepsikan konsumen pada kesadaran merek tinggi akan membantu asosiasi-asosiasi melekat pada merek tersebut karena daya jelajah merek tersebut akan menjadi tinggi di benak konsumen (Sudigdo dan Taufik, 2020).

Perilaku adalah kajian bagaimana individu, kelompok, dan organisasi memilih, membeli, menggunakan, dan memanfaatkan barang-barang, jasa layanan, gagasan, ataupun pengalaman untuk memuaskan kebutuhan dan keinginan mereka (Jusuf, 2018). Perilaku konsumen adalah tindakan yang langsung yang dilakukan konsumen dalam mendapatkan, mengkonsumsi dan menghabiskan produk dan jasa, termasuk proses keputusan yang mendahului dan mengikuti tindakan tersebut (Adnan, 2018).

Preferensi masyarakat sebagai konsumen adalah kemampuan konsumen dalam memilih barang mana yang lebih disukai dan melakukan ordering dari himpunan barang yang tersedia bagi konsumen untuk dipilih (Semaoen dan Kiptiah, 2013). Preferensi konsumen bersifat subyektif artinya preferensi yang dimiliki tiap individu bisa saja berbeda.
Ketidaksamaan ini selain disebabkan oleh perbedaan kebutuhan, kepentingan, keinginan, dan selera juga disebabkan oleh banyak faktor yang lain, yaitu pengalaman, kepercayaan, atribut, kepentingan, dan kepuasaan (Nurutami, 2019).

Dari beberapa penjabaran sebelumnya, dapat diketahui bahwa minat penggunaan ulang masyarakat terhadap dompet digital dipengaruhi oleh faktor, seperti persepsi, perilaku, dan preferensi masyarakat. Hal ini berarti penyedia layanan dompet digital perlu memahami dengan baik persepsi, perilaku, dan preferensi yang sesuai dengan pasar yang dituju dan berhasil memenangkan persaingan dengan pesaing dibidang yang sama (e-wallet). Beberapa temuan penelitian menunjukkan bahwa persepsi, perilaku, dan preferensi masyarakat memiliki pengaruh terhadap penggunaan ulang (Latifah, 2020; Ariana, Hufron, dan Basalamah, 2020; Apriyani dan Suharti, 2017). Maka dari itu, persepsi, perilaku, dan preferensi masyarakat berperan penting dalam mempengaruhi pertimbangan masyarakat untuk menggunakan ulang suatu produk jasa dompet digital (e-wallet) tersebut.

Analisis persepsi, perilaku, dan preferensi masyarakat terhadap penggunaan ulang dompet digital (e-wallet) OVO dapat dijadikan bahan penelitian yang menarik, karena dompet digital merupakan suatu produk yang penting khususnya bagi masyarakat di Surabaya yang memiliki mobilitas tinggi dan membutuhkan alat pembayaran yang praktis. Keberadaan dompet digital dapat membantu untuk memberikan kepraktisan dalam bertransaksi sehingga semakin lama cara transaksi tradisional dengan menggunakan uang tunai akan semakin ditinggalkan. Namun, pada proses transisi ini, tentunya terdapat pertimbangan 
tertentu dalam meyakinkan diri untuk menggunakan dompet digital sebagai alat transaksi utama. Masyarakat Surabaya tentunya memiliki pertimbangan tertentu dalam memilih layanan dompet digital yang digunakannya, karena tiap produk dompet digital memiliki karakteristik yang berbeda satu sama lain. Penelitian ini mengangkat persepsi, perilaku, dan preferensi masyarakat sebagai faktor yang memengaruhi penggunaan ulang dompet digital, karena penelitian mengenai penggunaan ulang terhadap dompet digital masih diperlukan penelitian yang lebih yang lanjut untuk mendapatkan temuan baru pada topik analisis persepsi, perilaku, dan preferensi masyarakat terhadap penggunaan ulang, terutama pada produk dompet digital.

\section{METODE PENELITIAN}

Penelitian ini dilakukan dengan menyebarkan kuesioner kepada 100 responden yang menjadi bagian dari penelitian yaitu masyarakat yang memiliki dan menggunakan dompet digital OVO di Surabaya. Kuesioner penelitian disebar melalui media sosial dalam bentuk google form. Metode pengambilan sampel yang dilakukan pada penelitian ini adalah non probability sampling dengan penentuan sampel yang digunakan yaitu teknik purposive sampling (Sugiyono, 2013:218) yaitu teknik pengambilan sampel sumber data dengan pertimbangan tertentu dimana pertimbangan dalam penelitian ini antara lain masyarakat yang memiliki dan menggunakan dompet digital OVO yang berdomisili di Kota Surabaya.

Tabel 1. Operasional Variabel

\begin{tabular}{lll}
\hline No & \multicolumn{1}{c}{ Variabel } & \multicolumn{1}{c}{ Indikator } \\
\hline 1 & $\begin{array}{l}\text { Persepsi adalah makna yang diperhatikan berdasarkan } \\
\text { pengalaman masa lalu, yaitu rangsangan (stimulus) yang } \\
\text { diperoleh melalui panca indera (Stanton dalam Sangadji } \\
\text { \& sopiah, 2013). }\end{array}$ & $\begin{array}{l}\text { Kemudahan } \\
\text { Keamanan }\end{array}$ \\
\hline 2 & $\begin{array}{l}\text { Perilaku konsumen adalah aktivitas, perilaku, dan proses } \\
\text { psikologis yang mendorong perilaku saat membeli, }\end{array}$ & Kebutuhan \\
& $\begin{array}{l}\text { menggunakan, dan mengonsumsi produk dan layanan } \\
\text { setelah melakukan operasi atau aktivitas evaluasi } \\
\text { sebelum membeli (Sumarwan, 2015). }\end{array}$ & Gaya Hidup \\
\hline 3 & $\begin{array}{l}\text { Preferensi konsumen adalah tahap evaluasi alternatif } \\
\text { dari proses keputusan pembelian, pada tahap tersebut } \\
\text { konsumen dihadapkan pada berbagai pilihan produk } \\
\text { dan jasa dengan berbagai atribut (Kotler dan Keller, } \\
\text { 2007). }\end{array}$ & Tren Budaya \\
\hline 4 & $\begin{array}{l}\text { Penggunaan ulang adalah perilaku dalam menggunakan } \\
\text { suatu produk atau jasa yang penggunaannya dilakukan } \\
\text { secara aktif berkelanjutan dalam jangka waktu tertentu } \\
\text { serta mempunyai sikap positif dan suka terhadap } \\
\text { produk atau jasa yang didasarkan pada pengalaman } \\
\text { penggunaan dimasa lampau (Suryana dan Dasuki, 2013). }\end{array}$ & Lespon Positif \\
\hline
\end{tabular}

Sumber: Peneliti, 2021 
Desain penelitian pada gambar 1 dibawah ini menunjukkan pengaruh antar variabel yang diteliti dalam penelitian ini yaitu Persepsi Masyarakat $\left(X_{1}\right)$, Perilaku Masyarakat $\left(X_{2}\right)$, Preferensi Masyarakat $\left(\mathrm{X}_{3}\right)$, dan Penggunaan Ulang (Y). Penggunaan dompet digital secara terus menerus akan menghasilkan perubahan perilaku konsumen dalam bertransaksi. Persepsi positif yang dirasakan masyarakat, perubahan perilaku dan preferensi masyarakat meningkatkan penggunaan ulang dompet digital OVO.

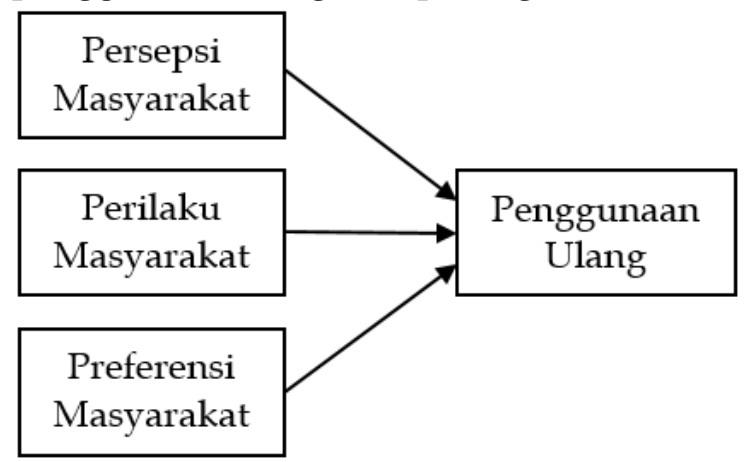

Gambar 1. Desain Penelitian

Metode penelitian yang digunakan dalam penelitian ini adalah metode penelitian kuantitatif yang meliputi uji validitas, uji reliabilitas, uji asumsi klasik (uji normalitas, uji multikolinearitas, uji heterokedastisitas), analisis regresi linier berganda, analisis uji $t$, uji $F$, dan koefisien determinasi.

\section{HASIL PENELITIAN}

\section{Responden}

Responden penelitian ini terdiri dari 37\% laki-laki dan $63 \%$ perempuan. Rentang usia responden yang terbanyak yaitu usia 18-22 tahun sebesar $82 \%$. Jenis status responden sebagian besar merupakan pelajar/mahasiswa sebesar $84 \%$ dan frekuensi penggunaan dompet digital dalam satu bulan paling banyak diatas $>3$ kali sebesar $46 \%$.

\section{Validitas Reliabilitas}

Seluruh item variabel dalam penelitian ini memiliki nilai $R$ hitung $\geq R$ tabel $(0,197)$ sehingga dinyatakan valid.

Tabel 2. Uji Validitas

\begin{tabular}{lcc}
\hline \multicolumn{1}{c}{ Variabel } & Item & R hitung \\
\hline Persepsi & X1.1 & 0,346 \\
& X1.2 & 0,306 \\
& X1.3 & 0,834 \\
& X1.4 & 0,696 \\
& X1.5 & 0,842 \\
& X1.6 & 0,715 \\
\hline Perilaku & X2.1 & 0,647 \\
& X2.2 & 0,311 \\
& X2.3 & 0,646 \\
& X2.4 & 0,690 \\
& X2.5 & 0,757 \\
Preferensi & X2.6 & 0,735 \\
\hline Penggunaan & X3.1 & 0,673 \\
Ulang & X3.2 & 0,708 \\
& X3.3 & 0,739 \\
& X3.4 & 0,766 \\
\hline & Y.1 & 0,583 \\
& Y.2 & 0,661 \\
& Y.3 & 0,824 \\
& Y.4 & 0,693 \\
& Y.5 & 0,802 \\
& 0,728 \\
\hline
\end{tabular}

Sumber: Data diolah, 2021

Tabel 3. Uji Reliabilitas

\begin{tabular}{lcc}
\hline \multirow{2}{*}{ Variabel } & \multicolumn{2}{c}{ Reliabilitas } \\
\cline { 2 - 3 } & Cronbach's & Sig \\
\hline Persepsi (X1) & 0,735 & 0,60 \\
Perilaku (X2) & 0,691 & 0,60 \\
Preferensi (X3) & 0,678 & 0,60 \\
Penggunaan Ulang (Y) & 0,824 & 0,60 \\
\hline
\end{tabular}

Sumber: Data diolah, 2021 
Seluruh butir pernyataan menghasilkan nilai Cronbach Alpha $\geq 0,60$ sehingga semua variabel dalam penelitian ini dinyatakan reliabel.

\section{Uji Asumsi Klasik}

Uji normalitas menunjukkan nilai signifikan $>0,05$ yaitu 0,2 sehingga dapat dinyatakan bahwa data terdistribusi secara normal. Uji multikolinieritas menunjukkan nilai VIF pada ketiga variabel bebas $<10$, yaitu 2,112 untuk variabel persepsi masyarakat, 2,047 untuk variabel perilaku masyarakat, dan 1,992 untuk variabel preferensi masyarakat, sehingga dapat disimpulkan bahwa data dalam penelitian ini tidak terdapat multikolinearitas. Diketahui bahwa plot atau titik-titik menyebar dan tidak membentuk suatu pola tertentu sehingga dapat disimpulkan bahwa tidak terjadi heteroskedastisitas.

\section{Uji Model}

Uji kelayakan model dapat disimpulkan layak dimana hasil pengujian mendapatkan nilai Sig. F sebesar 0,000 atau dibawah taraf uji penelitian sehingga Ho ditolak.

Tabel 4. Uji Koefisien Determinasi

\begin{tabular}{ccccc}
\hline Model & $\mathrm{R}$ & R Square & Adjusted R Square & $\begin{array}{c}\text { Std. Error of the } \\
\text { Estimate }\end{array}$ \\
\hline 1 & $.936^{\mathrm{a}}$ & .875 & .871 & 1.32043 \\
\hline
\end{tabular}

Sumber: Data diolah, 2021

Tabel 5. Uji F

\begin{tabular}{llccccc}
\hline & Model & Sum of Squares & df & Mean Square & F & Sig. \\
\hline \multirow{2}{*}{1} & Regression & 1174.980 & 3 & 391.660 & 224.634 & $.000^{\mathrm{b}}$ \\
& Residual & 167.380 & 96 & 1.744 & & \\
& Total & 1342.360 & 99 & & & \\
\hline
\end{tabular}

Sumber: Data diolah, 2021

Tabel 6. Analisis Regresi Linier Berganda

\begin{tabular}{llccccc}
\hline \multirow{2}{*}{ Model } & \multicolumn{2}{c}{ Unstandardized Coefficients } & $\begin{array}{c}\text { Standardized } \\
\text { Coefficients }\end{array}$ & \multirow{2}{*}{$\mathrm{t}$} & Sig. \\
\cline { 2 - 5 } & & $\mathrm{B}$ & Std. Error & Beta & & \\
\hline \multirow{2}{*}{1 (Constant) } & -6.768 & 1.194 & & -5.669 & .000 \\
& PERSEPSI & .753 & .063 & .626 & 11.944 & .000 \\
& PERILAKU & .204 & .059 & .178 & 3.446 & .001 \\
& PREFERENSI & .439 & .093 & .239 & 4.698 & .000 \\
\hline
\end{tabular}

Sumber: Data diolah, 2021 
Nilai koefisien determinan diketahui sebesar 0,875. Besaran angka koefisien determinasi (R Square) sama dengan $87,5 \%$. Angka tersebut memiliki arti yaitu variabel persepsi masyarakat (X1), perilaku masyarakat $(X 2)$, prefererensi masyarakat (X3) mempengaruhi penggunaan ulang (Y) sebesar $87,5 \%$, sisanya $12,5 \%$ dipengaruhi oleh variabel-variabel yang lain yang tidak dibahas dalam penelitian ini.

\section{Uji Hipotesis}

Persamaan regresi yang didapatkan tersaji pada tabel 6 sebagai berikut : $Y=-6.768+0,753 X_{1}+0,204 X_{2}+0,439 X_{3}$

Variabel persepsi masyarakat $\left(X_{1}\right)$ memiliki nilai $\mathrm{t}$ hitung sebesar 11,944 > t tabel sebesar 1,985 dengan tingkat signifikansi $0,000<0,05$ serta koefisien variabel 0,753 yang artinya jika persepsi masyarakat mengalami kenaikan, maka penggunaan ulang akan mengalami kenaikan sebesar 0,753 atau 75,3\%. Hal ini menunjukkan adanya pengaruh positif dan signifikan secara parsial antara variabel bebas $\left(X_{1}\right)$ dengan variabel terikat $(Y)$ sehingga dapat disimpulkan bahwa $\mathrm{H} 1$ diterima. Variabel perilaku masyarakat $\left(X_{2}\right)$ memiliki nilai t hitung sebesar 3,446 > $\mathrm{t}$ tabel sebesar 1,985 dengan tingkat signifikansi $0,001<0,05$ serta koefisien variabel sebesar 0,204 artinya jika perilaku masyarakat mengalami kenaikan, maka penggunaan ulang akan mengalami peningkatan sebesar 0,204 atau 20,4\%. Hal ini menunjukkan adanya pengaruh positif dan signifikan secara parsial antara variabel bebas $\left(\mathrm{X}_{2}\right)$ dengan variabel terikat (Y) sehingga dapat disimpulkan bahwa H2 diterima. Variabel preferensi masyarakat $\left(X_{3}\right)$ memiliki nilai t hitung sebesar 4,698 > $\mathrm{t}$ tabel sebesar 1,985 dengan tingkat signifikansi $0,000<0,05$ serta koefisien variabel sebesar 0,439 artinya jika preferensi masyarakat mengalami kenaikan, maka penggunaan ulang akan mengalami peningkatan sebesar 0,439 atau $43,9 \%$. Hal ini menunjukkan adanya pengaruh positif dan signifikan secara parsial antara variabel bebas $\left(X_{3}\right)$ dengan variabel terikat $(Y)$ sehingga dapat disimpulkan bahwa $\mathrm{H} 3$ diterima.

\section{PEMBAHASAN}

Penelitian ini menghasilkan temuan bahwa Persepsi, Perilaku, dan Preferensi masyarakat masing-masing memiliki pengaruh positif dan signifikan terhadap Penggunaan Ulang dompet digital (ewallet) OVO.

\section{Pengaruh Persepsi Masyarakat Terhadap Penggunaan Ulang}

Pada penelitian ini, diketahui bahwa persepsi masyarakat berpengaruh positif dan signifikan terhadap penggunaan ulang. Ini artinya masyarakat Surabaya memiliki persepsi yang positif terhadap aplikasi dompet digital OVO. Dengan pemahaman tersebut, masyarakat dapat menganalisa terlebih dahulu tentang hal-hal baru, seperti dalam proses penggunaan dompet digital. Ketika masyarakat mencoba menggunakan dompet digital, mereka akan memiliki pengalaman dan pendapat tentang dompet digital tersebut. Jika ini menciptakan kenyamanan, masyarakat dapat menggunakan kembali dompet digital OVO sebagai metode transaksi mereka.

Hasil penelitian ini memperkuat penelitian terdahulu yang dilakukan (Latifah, 2020) yang menyimpulkan bahwa variabel persepsi masyarakat berpengaruh signifikan terhadap penggunaan ulang. Selain itu juga memperkuat penelitian lainnya yang dilakukan oleh (Erviatin, 2019) yang menyimpulkan bahwa persepsi berpengaruh positif dan signifikan terhadap minat menggunakan. 


\section{Pengaruh Perilaku Masyarakat Terhadap Penggunaan Ulang}

Pada penelitian ini, diketahui bahwa perilaku masyarakat berpengaruh positif dan signifikan terhadap penggunaan ulang. Ini artinya perilaku masyarakat Surabaya mempengaruhi minat penggunaan ulang dompet digital OVO. Faktor yang mendasari minat penggunaan secara berulang adalah kemudahan yang diberikan kepada penggunanya seperti mengurangi kerumitan mencari uang dengan nominal yang waktu saat membayar atau masyarakat dapat berpergian kemana saja tanpa membawa uang cash akan menciptakan perilaku konsumen dalam hal bertransaksi, dimana menjadi sering menggunakan dompet digital secara terus menerus. Penggunaan dompet digital (e-wallet) OVO dianggap dapat memenuhi kebutuhan serta gaya hidup masyarakat yang semakin sering bertransaksi secara digital. Selain itu, banyaknya promo yang disediakan dapat memberikan menarik masyarakat untuk sering bertransaksi menggunakan dompet digital OVO.

Hasil penelitian ini juga memperketat penelitian terdahulu yang dilakukan oleh (Erviatin, 2019) yang menyimbulkan bahwa perilaku konsumen berpengaruh positif dan signifikan terhadap minat menggunakan. Selain itu juga memperkuat penelitian lainnya yang dilakukan oleh (Latifah, 2020) yang menyimpulkan bahwa perilaku masyarakat memiliki pengaruh secara parsial terhadap penggunaan ulang.

\section{Pengaruh Preferensi Masyarakat Terhadap Penggunaan Ulang}

Pada penelitian ini, diketahui bahwa preferensi masyarakat berpengaruh positif dan signifikan terhadap penggunaan ulang. Ini artinya masyarakat Surabaya menjadikan OVO sebagai preferensi utama aplikasi dompet digital yang digunakan. Preferensi adalah kesukaan, pilihan atau suatu hal yang lebih disukai konsumen. Setiap orang memiliki pertimbangan tersendiri ketika hendak menggunakan jasa. Preferensi dapat disebut dengan kata lain yaitu selera. Selera masing-masing orang ditentukan oleh banyak hal, mulai dari hobi, kondisi sosial, ekonomi hingga lingkungan hidupnya. Masyarakat yang merasa puas akan suatu dompet digital, akan cenderung memiliki preferensi untuk menggunakan dompet digital tersebut, dalam hal ini OVO telah memberikan kepuasan lebih dalam penggunaannya dibandingkan dengan aplikasi serupa lainnya, sehingga menjadi preferensi utama aplikasi dompet digital yang digunakan oleh masyarakat Surabaya.

Hasil penelitian ini juga memperkuat penelitian terdahulu yang dilakukan oleh (Erviatin, 2019) yang menyimpulkan bahwa preferensi berpengaruh positif dan signifikan terhadap minat menggunakan. Selain itu juga memperkuat penelitian lainnya yang dilakukan oleh (Annisa, 2016) yang menyimpulkan bahwa preferensi berpengaruh positif dan signifikan terhadap keputusan pembelian.

\section{KESIMPULAN}

Penelitian ini menghasilkan kesimpulan bahwa variabel persepsi masyarakat, perilaku masyarakat, dan preferensi masyarakat berpengaruh signifikan terhadap penggunaan ulang dompet digital (e-wallet) OVO di Kota Surabaya.

OVO harus lebih waspada dan selalu berinovasi dalam kinerja aplikasinya, serta memperhatikan dan meningkatkan fungsi, layanan aplikasinya tersebut. 


\section{DAFTAR PUSTAKA}

Adnan. (2018). Pengaruh Perilaku Konsumen terhadap Keputusan Pembelian Susu Morinaga di Kota Lhokseumawe. Jurnal Visioner \& Strategis, Vol. 7, No. 2, ISSN 2338-2864. DOI: https://journal.unimal.ac.id/visi/article/view/354

Annisa, Umi Wahyu. (2018). Analisis Pengaruh Persepsi, Preferensi dan Sikap Masyarakat Muslim Terhadap Keputusan Pembelian Jasa Perbankan Syariah (Studi Kasus di Kecamatan Mungkid Kabupaten Magelang). IAIN Salatiga. URI: http://erepository.perpus.iainsalatiga.ac.id/id/eprint/2522

Apriyani, N., \& Suharti. (2017). Analisis Pengaruh Persepsi Kebermanfaatan, Persepsi Kemudahan dan Kepercayaan terhadap Minat Beli Ulang Pengguna Smartphone Xiaomi, Jurnal Manajemen Dewantara, Vol. 1, No. 1, Hal. 21 - 34. DOI: 10.26460/md.v1i1.45

Ariana, R.R., Hufron, M., \& Basalamah, M.R. (2020). Pengaruh Persepsi Kemudahan Penggunaan dan Persepsi Manfaat Terhadap Minat Menggunakan Ulang Uang Elektronik OVO dengan Brand Awareness sebagai Variabel Intervening. Jurnal Ilmiah Riset Manajemen, Vol. 9, No. 20). DOI: http://riset.unisma.ac.id/index.php/jrm/article/view/8370

Aulia, Nabilah. (2019). Pengaruh Persepsi Kegunaan dan Kemudahan Penggunaan Pada Minat Penggunaan Quick Response Code dalam Transaksi Keuangan. E-Jurnal Akuntansi, Vol. 28, No. 3, ISSN. 1749-1766. DOI: https:// doi.org/10.24843/EJA.2019.v28.i03.p08

Basyar, Khoirul, \& Sanaji. (2016). Pengaruh Persepsi Kemudahan Dan Persepsi Manfaat Terhadap Niat Beli Ulang Secara Online Dengan Kepuasan Sebagai Variabel Intervening. Bisnis dan Manajemen (BISMA), Vol. 8, No. 2. DOI: http://dx.doi.org/10.26740/bisma.v8n2.p204$\underline{217}$

Erviatin. (2019). Pengaruh Persepsi, Preferensi dan Perilaku Konsumen Terhadap Minat Mahasiswa Uin Walisongo Semarang Menggunakan Jasa Transportasi Online Go-Jek. Walisongo Institutional Repository. URI: http://eprints.walisongo.ac.id/id/eprint/9643

Jayanti, F., \& Arista, A.T. (2018). Persepsi Mahasiswa Terhadap Pelayanan Perpustakaan Universitas Trunojoyo Madura. Journal of Management Studies, Vol. 12, No. 2. DOI: https:// doi.org/10.21107/ kompetensi.v12i2.4958

Jusuf, Dewi Indriani. (2018). Perilaku Konsumen Di Masa Bisnis Online. Yogyakarta: ANDI.

Kotler, P., \& Keller. (2007). Manajemen Pemasaran, Jilid I, Edisi Kedua belas, PT. Indeks, Jakarta.

Latifah, Imroatul. (2020). Pengaruh Persepsi, Perilaku, dan Preferensi Masyarakat terhadap Penggunaan Ulang Dompet Digital (E-Wallet) di Kabupaten Tulungagung. IAIN Tulungagung Institutional Repository. URI: http://repo.iaintulungagung.ac.id/id/eprint/17091

Nurutami, Diah Wulandani. (2019). Analisis Persepsi, Perilaku, dan Preferensi Masyarakat Terhadap Prinsip dan Produk Perbankan Syariah. Jakarta: Skripsi tidak diterbitkan.

Putri, R.R., \& Nugroho, D.A. (2015). Pengaruh Preferensi Merek, Persepsi Kualitas, Persepsi Harga dan Kepuasan Pelanggan Terhadap Minat Beli Ulang Shampoo Pantene (Studi Kasus pada Mahasiswi Konsumen Shampoo Pantene di Fakultas Ekonomi dan Bisnis Universitas Brawijaya Malang). Jurnal Ilmiah Mahasiswa FEB Universitas Brawijaya, Vol. 3, No. 2. DOI: https://jimfeb.ub.ac.id/index.php/jimfeb/article/view/1822 
Sangadji, E.M, \& Sopiah. (2013). Perilaku Konsumen - Pendekatan Praktis disertai, Himpunan Jurnal Penelitian. Yogyakarta: ANDI.

Sartika, Dewi. (2017). Analisis Faktor-Faktor Yang Mempengaruhi Minat Beli Ulang Produk You C 1000 Serta Dampaknya Terhadap Loyalitas Konsumen. Jurnal Penelitian Ekonomi dan Bisnis (JPEB), Vol. 1, No. 2, ISSN 2460-4291. DOI: 10.33633/jpeb.v2i1.2231

Semaoen, I., \& Kiptiyah, S.M. (2013). Mikroekonomi (Level Intermediate). Malang: UB Press, 2013), hal. 78.

Setiadi, Nugroho J. (2015). Perilaku Konsumen: Perspektif Kontemporer pada Motif, Tujuan, dan Keinginan Konsumen. Hal. 91-92.

Sudigdo, A., \& Taufik. (2020). Pengaruh Kesadaran Merek dan Persepsi Harga terhadap Keputusan Pembelian pada Lembaga Kursus Bahasa Sentra Lingua Depok. Jurnal Pengembangan Wiraswasta STIE IPWIJA, Vol. 22, No. 3. DOI: http://dx.doi.org/10.33370/jpw.v22i3.473

Sugiyono. (2013). Metode Penelitian Kuantitatif, Kualitatif dan RED, Bandung: Alfabeta.

Sumarwan, Ujang. 2015. Pemasaran Strategik:Prespektif Perilaku Konsumen, dan Marketing Plan. Jakarta: PT.Ghalia Indonesia.

Suryana, P., \& Dasuki E.S. (2013). Analisis Faktor yang Mempengaruhi Keputusan Pembelian dan Implikasinya pada Minat Beli Ulang. Jurnal Ekonomi Trikonomika, Vol. 12 No. 2 Hal. 190200, Desember 2013. DOI: http:// dx.doi.org/10.23969/trikonomika.v12i2.479 